\title{
A Study on Problems and Prospects of Environmental Disclosure from Stakeholders Point of View with Special Reference to Thrissur District
}

\author{
Remya. S1, Dr G.S Sandhya Nair ${ }^{2}$ \\ Assistant Professor \& Research Scholar, St Joseph's College (Autonomous), Irinjalakuda ${ }^{1}$ \\ Assistant Professor \& Research Guide, St Joseph's College (Autonomous), Irinjalakuda ${ }^{2}$
}

\begin{abstract}
Accounting and reporting for the environment have become an important dimension of corporate external information system in the twenty first century. The increasing pressure on companies to be responsible to the society has influenced them to operate in an environmentally responsible manner. The impact of environmental performance of an enterprise on its financial health has become a matter of growing concern to investors, creditors, government and public at large. As various stakeholders demand greater disclosure of environmental impacts and performance, a large number of companies all over the world have started reporting on these issues. The present study covers the various problems in Environmental disclosure. It also examines the various benefits arising from Environmental disclosure from stakeholders point of view. An attempt has been made to analyse the general format of Disclosure. An attempt has been made to understand the effect of CSR on Environmental disclosure has also been made.
\end{abstract}

Keywords: Environmental impact, Thrissur, Corporate, CSR.

\section{INTRODUCTION}

Environment includes all surroundings of a living organism. The relationship maintained by company and its stakeholders is not new. All organizations both in public and private sector have realized their importance to serve the shareholders. Now a day's shareholder is more concerned about the societal and environmental implications of business. Because of this, companies have started reporting on their societal and environmental performance apart from their financial performance.CSR reporting is a voluntary tool adopted by company to report both qualitative and quantitative information about the companies environmental activities.CSR reporting is also essential to attain the goal of corporate sustainability. The Global Reporting Initiative has become one of the most important concerns of financial industry. It is a widespread CSR reporting standard which is adopted internationally. The stakeholders are demanding for the periodic sustainability disclosure.

\section{LITERATURE REVIEW}

The institutional perspective of legitimacy theory is one of the dominant theories in social disclosure research (e.g. Deegan 2002; Patten \& Crampton 2004; Chen \& Robert 2010). Javier and Oscar Gonzalez-Benito (2010) investigated the effects of six relevant variables

on stakeholder environmental pressure perceived by industrial companies: size, internationalization, location of manufacturing activities, position in the supply chain, industrial sector, and managerial values and attitudes. Zemigala (2015) studied the main tendencies concerning the Environmental Management Systems' certification in the accordance with ISO 14001 and EMAS' registrations in the years 1999-2013 from a different countries' perspective. Bansal and Hunter (2003), as well as Darnall (2006) have evaluated the reasons why organizations adopt an EMS and the potential these environmental strategies have for improving the environment. In addition to that Steger (2000) took a review of smaller, mostly German, but also other European, empirical investigations of EMS in order to assess the impact that the EMSs have had on organizations. Ahlstrom et al. (2009) investigated articles about environment management published in Business Strategy and the Environment Journal during 2000-2006 and found that the majority of the articles do not reflect on its contribution to sustainable development and very few articles use alternative business models as examples. Recent studies highlight pressures from government, customers and various stakeholder groups as triggers for firms to effectively incorporate sustainability issues into their supply chain management (SCM) schemes (Nawrocka 2008a, 2008b; Seuring, Muller 2008). To answer the environmental concerns of stakeholders, including customers, specific 
Vol. 8, Issue 6, June 2021

DOI: $10.17148 /$ IARJSET.2021.8686

requirements need to be developed or the EMS needs to be customized, to accommodate environmental aspects connected to their own and suppliers' operations (Nawrocka 2008b).

\section{KEY WORDS}

Environmental Disclosure-Challenges of disclosure-Prospects of Disclosure-CSR

\section{OBJECTIVES OF THE STUDY}

- $\quad$ To study the general format of disclosure

- To analyse the stakeholder's attitude towards disclosure

- $\quad$ To understand the challenges of Environmental disclosure

- $\quad$ To understand the major benefits of environmental disclosure

- $\quad$ To study the effect of CSR on Environmental disclosure

\section{STATEMENT OF THE PROBLEM}

Environmental pollution is one of the most important problems that the world is facing today because of its health impact on workers and their performance on one hand and society on other hand even those who define the units objectives to increase profits in the short term realise that the society's image affects its profits and its ability to generate revenue. Therefore, taking environmental accounts into consideration, especially environmental costs, will make the accounting profession able to provide more relevant information to decision makers especially in productivity where the problem lies in the lack of information resulting in the adoption of improper decisions that contributed to the deterioration of the state of environment.

\section{SIGNIFICANCE OF THE STUDY}

The firms disclose environmental information voluntarily in their annual reports and websites. They provide environmental performance information and influence capital markets. The foreign companies are very much concerned about the issues like reputation, expectations of the society, legal requirements etc. as motives that encourage them to disclose environmental information. It provides information on what firms have done for the sake of community. It also helps in determining what they have contributed to the welfare of the society and what they will do in the future for the welfare and interest of the society.

\section{RESEARCH METHODOLOGY}

The study will be descriptive in nature. Both primary and secondary data has been used for the purpose of the study. The primary data will be collected through survey method among CEO, Company Secretaries, Chartered Accountants and senior accountants of the company using a well-structured questionnaire based on the study objective and expert opinion.

\subsection{Research Design:}

Method of sampling: Non probability sampling

Technique of sampling: Proportionate Multi stage Random Sampling

Population: Tyre Manufacturing industry in Thrissur district

Sample frame: Selected Tyre manufacturing industry in Thrissur district

Sample Unit: Each CEO, Company Secretary, Chartered Accountant and other senior accountants and managers in sample frame

Sample size: Size of the sample is 50

Tools for data Analysis: Percentage analysis, Ranking, Likert scale and Hypothesis testing

\section{ANALYSIS AND FINDINGS}

\subsection{General Format of CSR Disclosure}

$\bullet$ companies

The general format for annual report on CSR initiatives should be included in Board report by the qualifying

- $\quad$ It should provide a brief outlay of the companys CSR policy

- It should indicate an overview of the activities proposed to be undertaken by the company in the future.

- $\quad$ The company should mention about the composition of CSR committee 


\section{International Advanced Research Journal in Science, Engineering and Technology}

Vol. 8, Issue 6, June 2021

DOI: $10.17148 /$ IARJSET.2021.8686

- $\quad$ The company should provide web link to CSR policy

- It should disclose the Average net profit of the company for the last 3 financial years

- A note on the prescribed CSR expenditure should be provided-2\% of Average net profit)

- If the company could not spend $2 \%$ of average net profit due to some specific reasons, a proper mention of that reason should be made

- $\quad$ The entire details of the CSR projects taken during the year should be disclosed along with the following details

1.Total amount to be spend for the year

2.Amount carried forward from earlier years

3.Amount spend during the year

4.Amount carried forward for the year

- $\quad$ The report should be signed by CEO/MD/Director or chairman of CSR Committee

\subsection{Stakeholders attitude towards Sustainability Disclosure}

- $\quad$ Around $93 \%$ of the respondents were extremely aware about Environmental Disclosure and only 7\% were moderately aware about the environmental disclosure

- The main consequence of environmental erosion was wastage of valuable resources. The least consequence was compromised technology

- $\quad$ The main measures adopted to reduce environmental imbalances were providing liquidity support to various sectors including agriculture, expand social safety nets and food grants, upscale investments in social and economic infra structure, setting up of health support fund, extending the payment of taxes etc

- $\quad$ Around 96 percent of respondents were aware of CSR activities.52 percent have very clear knowledge about

CSR

- $\quad$ Out of 50 respondents,40 opined that company doing activities for promotion of health care

- 38 respondents opined that they do activities for conservation of nature

- All respondents opined that they do activities for promotion of education

- $\quad$ Majority of the respondents opined that they are not doing any activities for poverty alleviation

- Out of 50 respondents, 6 percent are with the opinion that environment is the key beneficiary of CSR,6 percent opined that it is women, 30 percent children, 20 percent agree that key beneficiary is disabled people and 30 percent opined that hospitals, old age homes etc are the key beneficiaries of CSR activities.

\section{- $\quad$ 8.3 Issues of Sustainability Reporting}

Table8.3 Issues of sustainability reporting

\begin{tabular}{|c|c|c|c|c|c|c|c|c|c|c|c|}
\hline Particulars & Weight & 7 & 6 & 5 & 4 & 3 & 2 & 1 & Total & Mean & Rank \\
\hline \multirow{2}{*}{ No economic value } & $\mathrm{F}$ & 19 & 9 & 7 & 10 & 2 & 3 & 0 & 50 & \multirow{2}{*}{5.48} & \multirow{2}{*}{2} \\
\hline & FX & 133 & 54 & 35 & 40 & 6 & 6 & 0 & 274 & & \\
\hline \multirow{2}{*}{$\begin{array}{l}\text { Social value cannot be } \\
\text { converted into money }\end{array}$} & $\mathrm{F}$ & 18 & 10 & 11 & 6 & 4 & 0 & 1 & 50 & \multirow{2}{*}{5.56} & \multirow{2}{*}{1} \\
\hline & $\mathrm{FX}$ & 126 & 60 & 55 & 24 & 12 & 0 & 1 & 278 & & \\
\hline \multirow{2}{*}{$\begin{array}{l}\text { Lack of accounting } \\
\text { standards for environmental } \\
\text { accounting }\end{array}$} & $\mathrm{F}$ & 1 & 4 & 14 & 12 & 8 & 6 & 5 & 50 & \multirow{2}{*}{3.8} & \multirow{2}{*}{4} \\
\hline & $\mathrm{FX}$ & 7 & 24 & 70 & 48 & 24 & 12 & 5 & 190 & & \\
\hline \multirow{2}{*}{ Not a legal obligation } & $\mathrm{F}$ & 5 & 1 & 2 & 5 & 11 & 9 & 17 & 50 & \multirow{2}{*}{2.78} & \multirow{2}{*}{7} \\
\hline & FX & 35 & 6 & 10 & 20 & 33 & 18 & 17 & 139 & & \\
\hline \multirow{2}{*}{$\begin{array}{l}\text { Lack of reliable industry } \\
\text { data }\end{array}$} & $\mathrm{F}$ & 2 & 3 & 4 & 5 & 8 & 19 & 9 & 50 & \multirow{2}{*}{2.86} & \multirow{2}{*}{6} \\
\hline & $\mathrm{FX}$ & 14 & 18 & 20 & 20 & 24 & 38 & 9 & 143 & & \\
\hline \multirow{2}{*}{ Inapplicable assumption } & $\mathrm{F}$ & 3 & 7 & 1 & 9 & 12 & 7 & 11 & 50 & \multirow{2}{*}{3.3} & \multirow{2}{*}{5} \\
\hline & $\mathrm{FX}$ & 21 & 42 & 5 & 36 & 36 & 14 & 11 & 165 & & \\
\hline $\begin{array}{l}\text { Environmental costs will } \\
\text { not be recorded }\end{array}$ & $\mathrm{F}$ & 2 & 16 & 11 & 3 & 5 & 6 & 7 & 50 & 4.22 & 3 \\
\hline
\end{tabular}

The main challenge in connection with disclosure is social values cannot be converted into money and the least challenge is the disclosure is not a legal obligation. 
International Advanced Research Journal in Science, Engineering and Technology

Vol. 8, Issue 6, June 2021

DOI: $10.17148 / I A R J S E T .2021 .8686$

\subsection{Prospects of Environmental Disclosure}

Table 8.4 Benefits of Sustainability Reporting

\begin{tabular}{|l|c|c|c|c|c|c|c|c|c|c|c|c|c|}
\hline \multicolumn{1}{|c|}{ Particulars } & R1 & W5 & R2 & W4 & R3 & W3 & R4 & W2 & R5 & W1 & Weight & Mean & Rank \\
\hline $\begin{array}{l}\text { Build up } \\
\text { confidence in the } \\
\text { community }\end{array}$ & 4 & 20 & 16 & 64 & 6 & 18 & 14 & 28 & 10 & 10 & 140 & 2.8 & IV \\
\hline $\begin{array}{l}\text { Improved } \\
\text { competitive } \\
\text { advantage }\end{array}$ & 8 & 40 & 12 & 48 & 18 & 54 & 4 & 8 & 8 & 8 & 158 & 3.16 & II \\
\hline $\begin{array}{l}\text { Improved } \\
\text { wellbeing and } \\
\text { welfare of } \\
\text { workers }\end{array}$ & 10 & 50 & 10 & 40 & 12 & 36 & 6 & 12 & 12 & 12 & 150 & 3 & III \\
\hline $\begin{array}{l}\text { Improved } \\
\text { ecofriendly } \\
\text { processes }\end{array}$ & 8 & 40 & 8 & 32 & 6 & 18 & 18 & 36 & 10 & 10 & 136 & 2.72 & V \\
\hline $\begin{array}{l}\text { Improvement in } \\
\text { company sales } \\
\text { and profitability }\end{array}$ & 20 & 100 & 4 & 16 & 8 & 24 & 8 & 16 & 10 & 10 & 166 & 3.32 & I \\
\hline
\end{tabular}

Source: Primary Data

From the above table it can be understood that the main benefit derived from disclosure is Improvement in sales and profitability of the company and the least benefit is improved eco friendly processes

\subsection{Analysis of Effect of CSR on Environmental disclosure}

The 8 additional questions relating to impact of CSR on Sustainability reporting has been asked to respondents. For analysis purpose, these questions have assigned numbers as 1,2,3,4,5,6,7 and 8 respectively. All questions have only two answers Yes or No. And also it measures the extend by putting options like very high, high, moderate, low and very low. For analysis, these options assigns rank as 5, 4,3,2,1 respectively. Each respondent is then graded on the basis of scores obtained for the "Sustainability Disclosure" as follows:

\section{5-1.5 Very low effect on disclosure}

1.5-2.5 Low effect on disclosure

2.5-3.5 Moderate effect on disclosure

3.5-4.5 High effect on disclosure

4.5-5.5 Very high effect on disclosure

The results of the analysis are made through the scaling technique which is showed below.

Measurement of effect of CSR on Sustainability disclosure through scaling technique

\begin{tabular}{|c|c|c|c|c|c|c|c|c|c|c|}
\hline SL No & $\mathbf{1}$ & $\mathbf{2}$ & $\mathbf{3}$ & $\mathbf{4}$ & $\mathbf{5}$ & $\mathbf{6}$ & $\mathbf{7}$ & $\mathbf{8}$ & Total & Average \\
\hline 1 & 5 & 5 & 4 & 5 & 4 & 4 & 4 & 4 & 35 & 4.37 \\
\hline 2 & 4 & 4 & 4 & 4 & 3 & 3 & 5 & 4 & 31 & 3.87 \\
\hline 3 & 4 & 3 & 3 & 4 & 2 & 4 & 5 & 3 & 28 & 3.5 \\
\hline 4 & 5 & 4 & 3 & 5 & 3 & 4 & 5 & 3 & 32 & 4 \\
\hline 5 & 5 & 3 & 4 & 4 & 4 & 4 & 5 & 4 & 33 & 4.12 \\
\hline 6 & 4 & 4 & 3 & 5 & 2 & 3 & 5 & 4 & 30 & 3.75 \\
\hline 7 & 5 & 4 & 4 & 4 & 4 & 4 & 5 & 4 & 34 & 4.25 \\
\hline 8 & 3 & 3 & 3 & 2 & 4 & 3 & 3 & 4 & 25 & 3.12 \\
\hline 9 & 4 & 4 & 3 & 3 & 3 & 4 & 4 & 4 & 29 & 3.62 \\
\hline 10 & 5 & 5 & 4 & 5 & 4 & 5 & 5 & 4 & 37 & 4.62 \\
\hline 11 & 4 & 4 & 4 & 3 & 4 & 3 & 5 & 4 & 31 & 3.87 \\
\hline 12 & 5 & 4 & 4 & 4 & 3 & 3 & 5 & 3 & 31 & 3.87 \\
\hline 13 & 5 & 3 & 4 & 5 & 5 & 4 & 5 & 4 & 35 & 4.37 \\
\hline 14 & 4 & 4 & 3 & 4 & 3 & 3 & 5 & 4 & 30 & 3.75 \\
\hline 15 & 4 & 4 & 4 & 4 & 3 & 4 & 5 & 4 & 32 & 4 \\
\hline 16 & 5 & 3 & 5 & 5 & 5 & 5 & 5 & 4 & 37 & 4.62 \\
\hline 17 & 4 & 4 & 3 & 4 & 4 & 3 & 4 & 4 & 30 & 3.75 \\
\hline
\end{tabular}


International Advanced Research Journal in Science, Engineering and Technology

Vol. 8, Issue 6, June 2021

DOI: $10.17148 /$ IARJSET.2021.8686

\begin{tabular}{|c|c|c|c|c|c|c|c|c|c|c|}
\hline 18 & 4 & 4 & 3 & 5 & 4 & 3 & 5 & 4 & 32 & 4 \\
\hline 19 & 5 & 5 & 4 & 5 & 5 & 4 & 5 & 5 & 38 & 4.75 \\
\hline 20 & 4 & 4 & 3 & 4 & 2 & 3 & 4 & 3 & 27 & 3.37 \\
\hline 21 & 5 & 4 & 4 & 5 & 5 & 4 & 5 & 4 & 36 & 4.75 \\
\hline 22 & 3 & 3 & 2 & 4 & 2 & 2 & 4 & 3 & 23 & 2.87 \\
\hline 23 & 4 & 4 & 4 & 4 & 5 & 4 & 5 & 4 & 37 & 4.25 \\
\hline 24 & 4 & 4 & 2 & 3 & 5 & 5 & 5 & 5 & 33 & 4.12 \\
\hline 25 & 4 & 5 & 4 & 5 & 5 & 4 & 5 & 4 & 36 & 4.5 \\
\hline 26 & 4 & 3 & 4 & 4 & 3 & 4 & 5 & 4 & 31 & 3.87 \\
\hline 27 & 5 & 4 & 4 & 4 & 4 & 5 & 4 & 4 & 34 & 4.25 \\
\hline 28 & 5 & 4 & 3 & 4 & 5 & 2 & 3 & 4 & 30 & 3.75 \\
\hline 29 & 3 & 3 & 5 & 4 & 4 & 4 & 3 & 3 & 29 & 8.62 \\
\hline 30 & 5 & 4 & 3 & 4 & 3 & 3 & 3 & 3 & 28 & 3.5 \\
\hline 31 & 3 & 5 & 4 & 3 & 4 & 3 & 4 & 3 & 29 & 3.62 \\
\hline 32 & 3 & 4 & 4 & 3 & 3 & 3 & 3 & 3 & 26 & 3.25 \\
\hline 33 & 2 & 4 & 5 & 3 & 3 & 4 & 4 & 3 & 28 & 3.5 \\
\hline 34 & 2 & 5 & 4 & 4 & 3 & 3 & 2 & 3 & 26 & 3.62 \\
\hline 35 & 4 & 3 & 4 & 3 & 3 & 4 & 3 & 4 & 28 & 3.5 \\
\hline 36 & 5 & 4 & 5 & 4 & 3 & 4 & 3 & 4 & 32 & 4 \\
\hline 37 & 4 & 5 & 5 & 4 & 4 & 3 & 3 & 3 & 31 & 3.87 \\
\hline 38 & 4 & 4 & 4 & 3 & 4 & 2 & 3 & 4 & 28 & 3.5 \\
\hline 39 & 3 & 4 & 4 & 4 & 2 & 3 & 3 & 3 & 26 & 3.25 \\
\hline 40 & 2 & 3 & 4 & 3 & 3 & 3 & 4 & 3 & 25 & 3.12 \\
\hline 41 & 4 & 3 & 4 & 4 & 3 & 3 & 3 & 3 & 27 & 3.37 \\
\hline 42 & 4 & 3 & 4 & 5 & 3 & 3 & 3 & 4 & 29 & 3.62 \\
\hline 43 & 5 & 4 & 4 & 4 & 3 & 3 & 4 & 3 & 30 & 3.75 \\
\hline 44 & 4 & 4 & 4 & 3 & 4 & 3 & 3 & 3 & 28 & 3.5 \\
\hline 45 & 4 & 5 & 3 & 4 & 3 & 4 & 4 & 4 & 31 & 3.87 \\
\hline 46 & 5 & 4 & 3 & 3 & 3 & 3 & 4 & 3 & 28 & 3.5 \\
\hline 47 & 5 & 4 & 5 & 4 & 3 & 3 & 3 & 2 & 29 & 3.62 \\
\hline 48 & 3 & 3 & 3 & 4 & 3 & 3 & 4 & 3 & 26 & 3.25 \\
\hline 49 & 3 & 4 & 4 & 3 & 3 & 3 & 2 & 3 & 25 & 3.12 \\
\hline 50 & 3 & 4 & 5 & 3 & 4 & 5 & 4 & 3 & 31 & 3.87 \\
\hline Total & 203 & 195 & 189 & 203 & 176 & 175 & 202 & 183 & & 189 \\
\hline Average & 4.06 & 3.9 & 3.78 & 4.06 & 3.52 & 3.5 & 4.04 & 3.66 & & 3.78 \\
\hline
\end{tabular}

Source: Sample Survey

The result is obtained by the average of the individual scores. The figure shows 3.78 which indicate high effect of Covid 19 on disclosure.

\section{CONCLUSION}

Environmental accounting and reporting is preliminary stage in India. The environment ministry has issued instruction in this regard to prepare environment statement. The main information given in this statement are types of devices installed for pollution control, steps taken for energy conservation, steps taken for raw material production conservation, steps taken for waste water and production process waste etc. Very few corporations disclose adequate information regarding environmental issue. It is also revealed that most of the companies disclose environmental information in a 


\section{International Advanced Research Journal in Science, Engineering and Technology}

Vol. 8, Issue 6, June 2021

DOI: $10.17148 /$ IARJSET.2021.8686

descriptive manner. Although executives are fully aware of the requirements of environmental disclosure, companies give very little information in their annual reports

\section{REFERENCES}

[1]. Freedman M,and Jaggi M (1998)An analysis of the association between pollution disclosure and economic performance Accounting, Auditing and Accountability Journal pp 43-58

[2]. Sharma S (2000) Managerial interpretations and Organisational context as predictors of corporate choice of environmental strategy, Academy of management Journal pp681-697

[3]. Cowen, S. S., Ferreri, L. B., \& Parker, L. D. (1987). The impact of corporate characteristics on social responsibility disclosure: A typology and frequency-based analysis. Accounting, Organisations and Society, 12(2), 111-122.

[4]. Remya S. "Covid19 and Environment-A Theoretical Review from Higher Education Students Perspective". International Research Journal on Advanced Science Hub, 2, Special Issue ICARD 2020, 2020, 227-230. doi: 10.47392/irjash.2020.124

[5]. Gray, R., Javad, M., Power, D. M., \& Sinclair, C. D. (2001). Social and environmental disclosure and corporate characteristics: A research note and extension. Journal of Business Finance and Accounting, 28(3-4), 327-356.

[6]. Hackston, D., \& Milne, M. J. (1996). Some determinants of social and environmental disclosures in New Zealand companies. Accounting, Auditing and Accountability Journal, 9(1), 77-108.

[7]. Milne, M. J., \& Adler, R. W. (1999). Exploring the reliability of social and environmental disclosures content analysis. Accounting, Auditing and Accountability Journal, 12(2), 237-256. 